\title{
PROFESSIONAL SUPPORT MEASURES FOR TEACHERS IN REGIONS OF LATVIA
}

\author{
Anda Grinfelde ${ }^{1}$, Dr.oec.; Liga Paula², Dr.sc.soc.; Ilze Prizevoite ${ }^{3}$, Mg.oec.; and Inga \\ Vanaga ${ }^{4}$, Mg.sc.soc. \\ 1,2Latvia University of Life Sciences and Technologies, ${ }^{3,4}$ Latvian Trade Union of Education and Science \\ Employees
}

\begin{abstract}
The authors in the paper present the results of the on-line survey on teachers' professional support measures which was carried out in collaboration with the Latvian Trade Union of Education and Science Employees. The aim of the research was to explore, how teachers assessed availability and level of professional support measures within a context of current education reforms. The quantitative research design was used in the study and the quantitative survey of the teachers was conducted via web tool visidati.lv $(n=1258)$ from November 2 till November 27, 2018. The questionnaire comprised the statements on following measures of professional support: financial, material and technological, methodological, and societal. Teachers' opinions regarding their provision with resources and support were analysed by region. The results witness about regional disparities mainly between Riga and Latgale regions. There are statistically significant differences between both regions in how teachers are provided with health insurance. The need for financial and societal support was assessed as most important for teachers in Riga region, while Latgale teachers considered the need for methodological and material support. Teachers in Zemgale more often than the respondents from other regions agreed with the statement that when integrating students with special needs into general education institutions, teachers are not paid for additional duties. The authors conclude that different professional support measures are available for teachers in Latvia, but there is No common support system in place to address which functions and support measures should be implemented at national level and which at municipal level.
\end{abstract}

Key words: educational institutions, professional support, regions, teachers.

JEL code: R23, K31.

\section{Introduction}

The support that teachers need includes financial, material and methodological support, as well as broader public awareness and involvement in the implementation of reforms. Policy pointers of the European Union "highlight the need for incentives to be set to ensure investment in teachers' and trainers' professional development, taking into account the differing needs of each role" (European Union, 2018, p.3). The development of professional competencies and the extent to which the specially designed teachers' professional competence development programs should be ensured in Latvia is determined by the Cabinet of Ministers Regulations No. 569 (Noteikumi par pedagogiem $\ldots, 2018)$. They concern the general competences of the teacher, the content of the education and didactics, and the management of education. Although the offer is diverse, teachers admit that socially and technologically changing conditions require more up-to-date content measures than they are available to date. To some extent this is acknowledged also in other studies (for example, Sprott, 2018). Each country looks for the appropriate way how to support educators at both national and local levels. As OECD report states, „in half of the OECD countries and economies with available data, school heads and teachers working in a disadvantage or remote area are rewarded with additional compensation" (OECD, 2018:26).

To understand the broader picture and opinions of the teachers in Latvia, the Latvian Trade Union of Education and Science Employees (LIZDA) conducted a web-survey in autumn, 2018. The aim of

\footnotetext{
${ }^{1}$ Anda.Grinfelde@llu.Iv, +37129265476

2 Liga.Paula@llu.Iv, +37126321667

3 ilze.prizevoite@lizda.Iv, +37126683551

4 inga.vanaga@lizda.Iv, +371 25998994
} 
the research was to explore, how teachers assessed availability and level of professional support measures within a context of current education reforms. The following tasks of the study were defined: (1) to identify problems in various aspects related to teachers 'professional support, (2) to compare results across regions and Latvia as a whole, and (3) to develop proposals for the improvement of teachers' professional support. The article presents the results of the LIZDA study, which focus on the assessment and improvement of the professional support of teachers.

\section{Research methodology}

Quantitative research strategy was used for the research. The questionnaire was developed and posted on the webpage visidati.Iv and was available from November 2 till November 27, 2018. Information about the survey was disseminated via LIZDA homepage, trade union's member organizations in schools, social media, and website eklase.lv. The questionnaire comprised the statements on various measures of professional support: financial, material and technological, methodological, and societal. All these measures were assessed within a context of current education reforms: (1) support for the introduction of competence-based content; (2) support for novice teachers; (3) support for the provision of inclusive education; (4) support for principals of educational establishments. The respondents were offered to use symmetric 5-point Likert scale (strongly agree, slightly agree, neither agree nor disagree, slightly disagree, strongly disagree) in order to assess the statements. The teachers' survey was conducted on the basis of the methodological and ethical principles of the online survey (Roberts \& Allen, 2015; Toepoel, 2015). The survey was anonymous and the results were used only in an aggregated way.

The research sample was made of 1258 respondents, more than half of whom (68\%) were LIZDA members. Of the teachers surveyed, $40 \%$ lived in cities, while $60 \%$ lived in rural municipalities. Among the respondents, $94 \%$ were women and $6 \%$ were men. The teachers surveyed represented all planning regions of Latvia: Vidzeme (25\%), Kurzeme (15\%), Zemgale (18\%), Latgale (24\%) and Riga region (18\%). Respondents represented all levels of education (preschool, elementary school, primary school, secondary school) and positions; they were with different seniority and represented different age groups.

For the descriptive analysis of quantitative data mean (M) was calculated by using statistical program SPSS (Statistical Package for Social Science v21) and Independent samples t-test was calculated to analyse differences in opinions of the respondents representing different regions.

\section{Research results and discussion}

\section{Teachers' views on their professional support in Latvia's planning regions}

The main areas of support in the research were related to support for the implementation of competence-based content, support for novice teachers, support for inclusive education and support for principals of educational institutions. The comparison of teachers' professional support in Latvia's planning regions was performed by comparing the views of teachers on available provision with resources for teaching methods, materials for technical, financial and public support. Figure 1 shows which types of support teachers considered as the priority for their professional development.

Methodological support as very important was most often assessed in Latgale (51\%) and Kurzeme (47\%). Material and technological support was assessed as the most significant in Latgale region (43\%), while societal support in Riga region (44\%). In general, the survey results revealed that in the regions of Latgale and Riga teachers were more likely to assess all forms of professional support as important, so they felt the need for aid. In teachers' opinions of the regions of Riga and 
Latgale, contrary to the comparison of all other regions, were statistically significant differences $(p<0.05)$ in assessment of importance of all support measures: financial support (Riga $M=1.90$; Latgale $M=1.92$ ); material and technological support (Riga $M=2.11$; Latgale $M=2.05$ ); methodological support (Riga $M=2.24$; Latgale $M=1.97$ ); societal support (Riga $M=2.15$; Latgale $M=2.22$ ).

In general, teachers of Latvia assessed financial support (50\%) and methodological support (44\%) as a priority. Technical support (38\%) and societal support (38\%) were equally important. As a priority, the financial support was more often assessed by teachers in the regions of Riga ( $55 \%$ ) and Latgale (52\%), although Riga teachers have higher average wages compared to other regions, but less frequently in the region of Kurzeme (44\%).

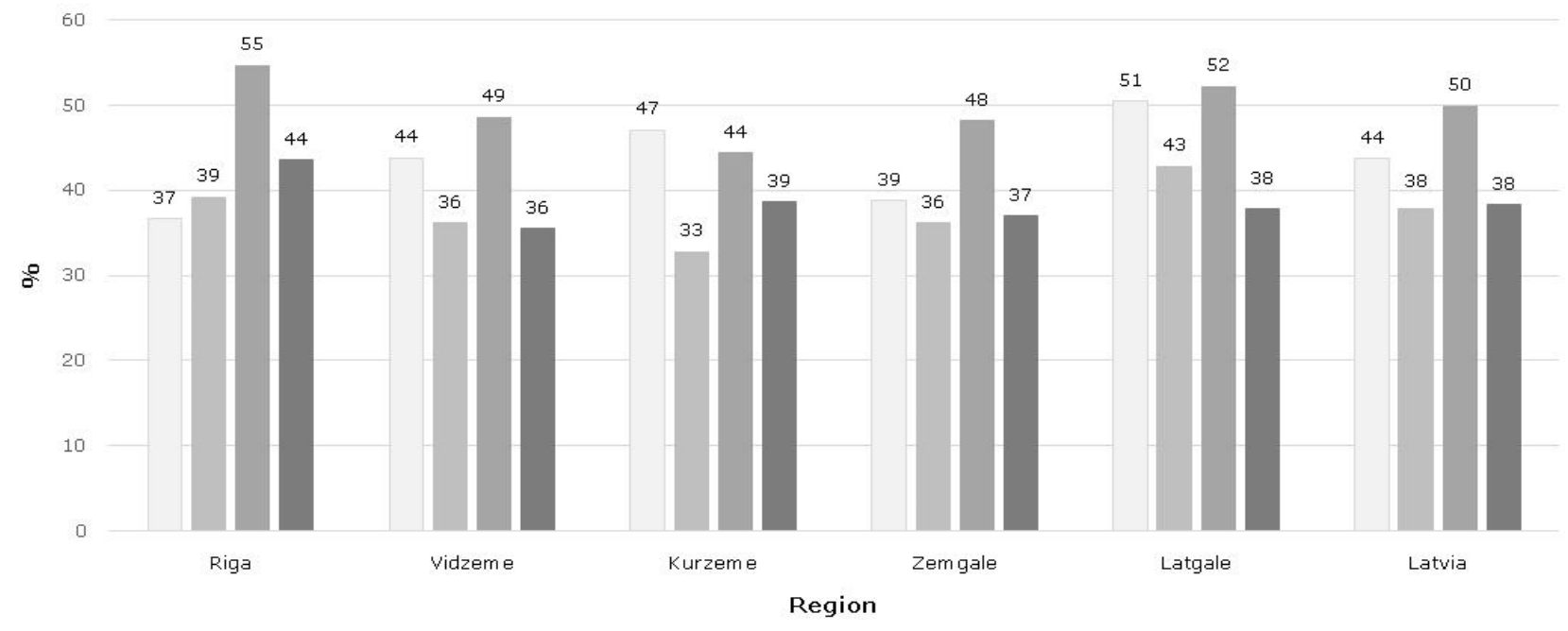

Methodological support Material and technological support $\quad$ Financial support $\quad$ Societal support

Source: Authors' calculations based on LIZDA survey data

Fig. 1. Teachers' views on the importance of types of their professional support (aggregate of the assessments 'strongly agree' and 'slightly agree', \%), $n=1258$

\section{Financial support}

As part of the study, teachers were asked to assess the statements related to the lower salary rate and the motivation of young people for the work of the teacher and for additional obligations regarding inclusive education (see Figure 2 ). Nearly all teachers agreed $(90 \%)$ that the lowest rate of wages for teachers set out in the regulatory enactments does not increase the prestige of the profession ( $92 \%$ of Riga teachers supported this statement) and believed that the salary rate of the teacher cannot be lower than the average salary in the country, multiplied by a factor of 1.2 (93\% of Riga and $94 \%$ of Vidzeme respondents). The regions of Riga and Latgale had statistically significant differences in teachers opinions ( $p<0.05$, Riga $M=1.36$, Latgale $M=1.55$ ), as well as the regions of Riga and Zemgale $(p<0.05$, Riga $M=1.36$, Zemgale $M=1.46)$. Vidzeme teachers more frequently $(97 \%)$ than the respondents on average ( $93 \%$ ) agreed that teacher remuneration is not motivating for young people to choose a job in this profession. Zemgale teachers more often $(81 \%)$ than teachers in the country on average $(75 \%)$ agreed with the statement that when students with special needs are integrated in general education institutions, teachers are not paid for any additional duties. Regarding this statement, the regions of Riga and Latgale have statistically significant differences ( $p<0.05$, Riga $M=1.36$, Latgale $M=1.64$ ). 


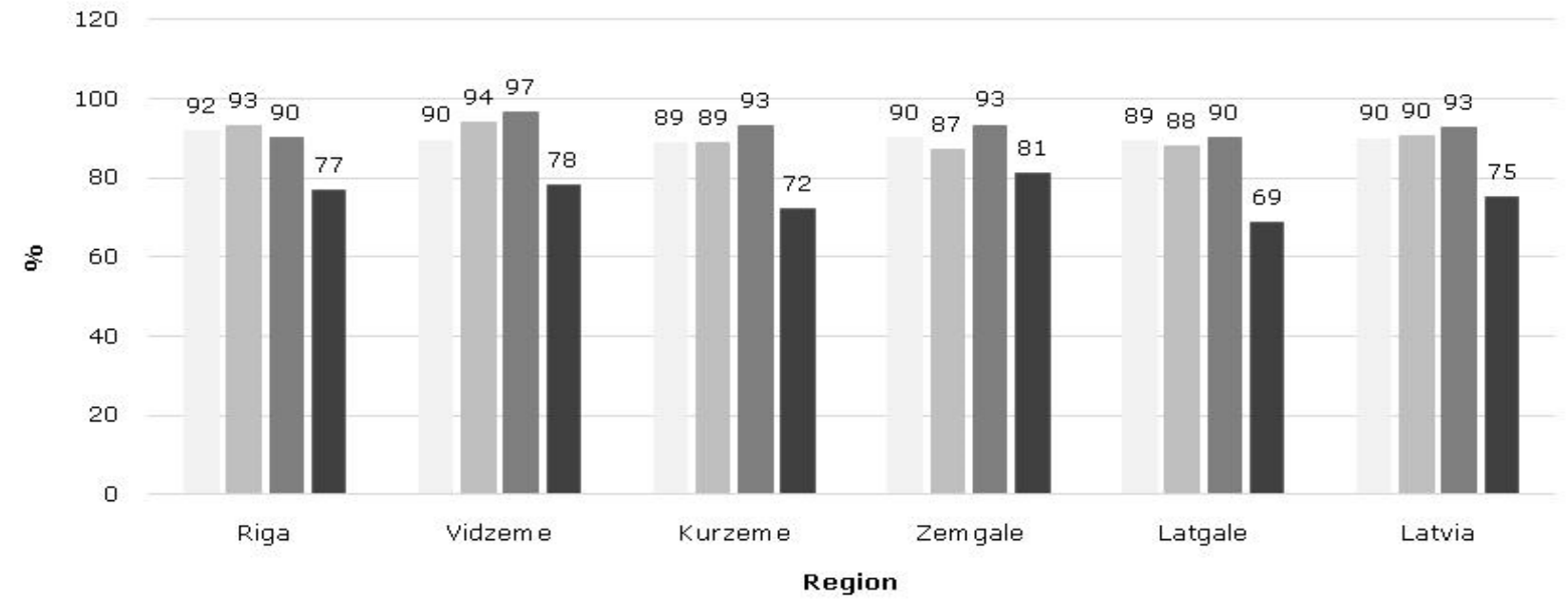

The lowest salary rate specified in regulatory enactments does not increase the prestige of the teaching profession

I believe that the teacher's salary rate cannot be lower than the average salary in the country, multiplied by a factor of 1.2

- Teacher salary is not motivating for young people to choose a job in this profession

- When integrating students with special needs into general education institutions, teachers are not paid for all additional duties

Source: Authors' calculations based on LIZDA survey data

Fig. 2. Teachers' assessment on salary and motivation for work (aggregate of the assessments 'strongly agree' and 'slightly agree', \%), $\mathbf{n = 1 2 5 8}$

Teacher ratings on the statements of job motivation factors (aggregate of answers 'strongly agree' and 'slightly agree') are presented in Figure 3.

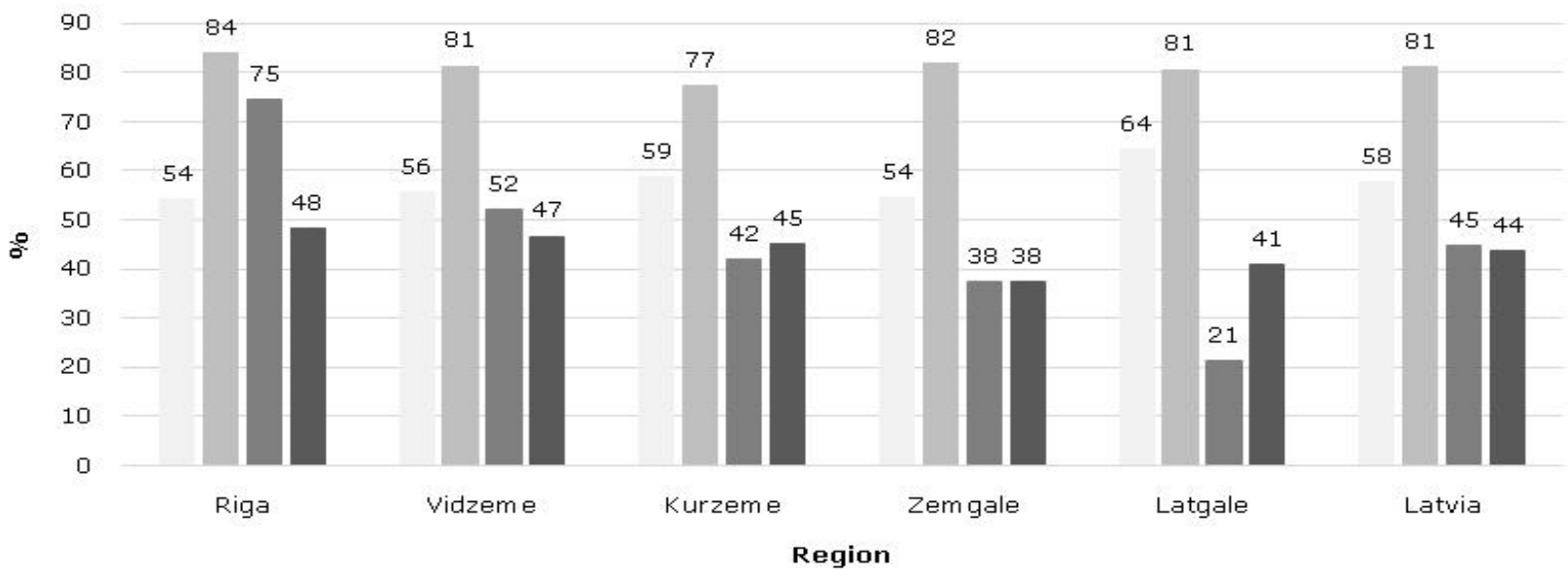

I've had to pay for my teacher's professional training from my private means in the last three years

I welcome the possibility of creative leave, which is introduced in other countries, for example, getting one month of leave each year or six months after six years of in-service

In the school I work, educators are provided with a health insurance

In the school I work, teachers are provided with cost catering

Source: Authors' calculations based on LIZDA survey data

Fig. 3. Assessment of teachers on motivational factors for work in the education sector (aggregate of the assessments 'strongly agree' and 'slightly agree', \%), $\mathbf{n = 1 2 5 8}$

In Latgale, teachers more often (64\%) than average in Latvia (58 \%) strongly agreed and slightly agreed that they have funded their teacher's professional development from their private resources over the last three years. The regions of Riga and Latgale, contrary to the comparison of all other regions, had statistically significant differences $(p<0.05$, Riga $M=2.87$, Latgale $M=2.42)$ regarding this statement. Around $80 \%$ of the respondents in all regions strongly agreed or slightly agreed they 
value positive experience of other countries in giving teachers creative leave. There were No statistically significant differences in teachers' opinions between regions regarding this statement. Regarding provision of health insurance there are statistically significant differences between the regions of Riga and Latgale $(p<0.05)$; in the region of Riga the $75 \%$ of the respondents have received health insurance, while in Latgale there were only $21 \%$, which is the least result in comparison to all other regions. Approximately 40-50\% of teachers in all regions had cost catering; there were No statistically important regional differences in this.

\section{Methodological support}

When comparing the statements on cooperation for the development of professional skills in the educational establishment (see Figure 4), it should be concluded that there were No statistically significant differences between regions and all regions equally dominated by the notion that the educational establishment understands and accepts the necessary changes in the new teaching content and teaching approach, and that teachers receive answers to questions about the new competence-based content and approach from the school leaders. There was a significant difference between Riga and Latgale regions: in Riga $29 \%$ of teachers received answers to questions about the new competence-based content and accessed support from an education specialist in local municipality, while in Latgale $61 \%$ of the respondents reported on positive experience. In all regions, equally around $60 \%$ of the teachers acknowledged that the educational institution was aware of the needs for new, necessary competencies.

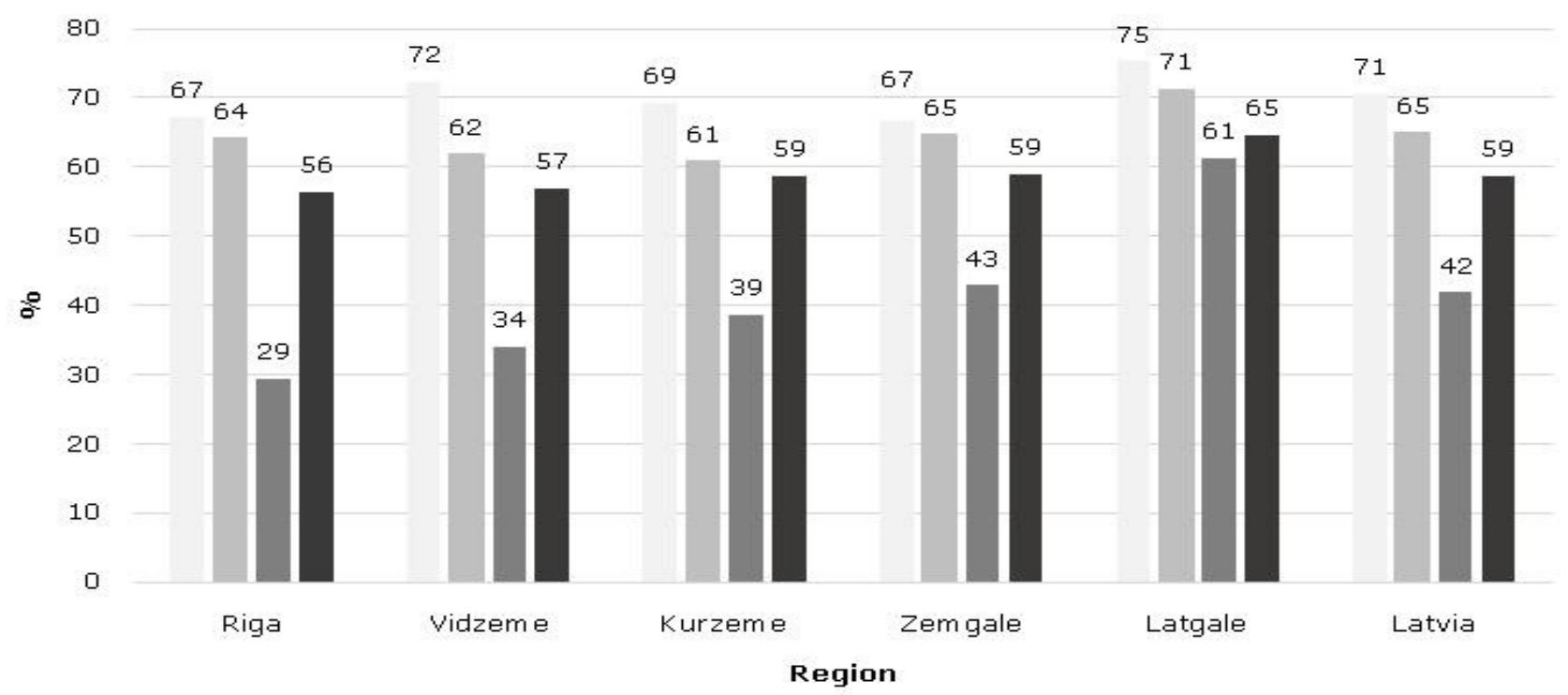

The teaching staff in my school understands and accepts the necessary changes in the new curriculum and teaching approach

I can get answers from the management of my school to questions about the new competence-based content and approach

- I can get answers from a education specialist of local government to questions about the new competence-based content and approach

- The school in which I work identifies my needs for new competences

Source: Authors' calculations based LIZDA survey data

Fig. 4. Teachers' assessment on cooperation to improve professionalism in the educational establishment (aggregate of the assessments 'strongly agree' and 'slightly agree', \%), $n=1258$

There are No statistically significant differences between regions in teacher opinions on cooperation to improve professionalism in educational establishments for the implementation of competence-based content (see Figure 5). The study shows that fewer (average $56 \%$ ) teachers are 
given the opportunity to meet once a week to study together, but more often (average $73 \%$ ) teachers believe that they are promoted to share experience.

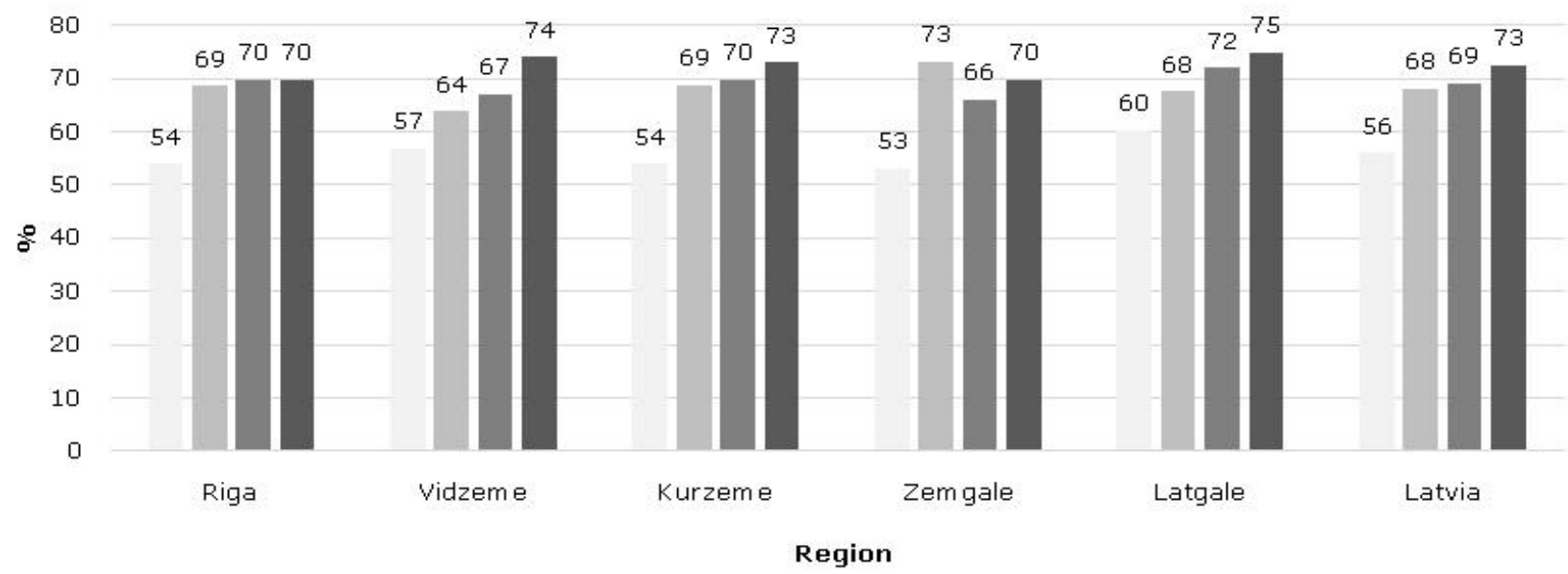

The school I work for provides an opportunity for techers to meet once a week to study together

In In the school I work, teachers watch each other's lessons

a In the school I work, mutual support between teachers for the implementation of competence-based learning content is promoted

- The school I work for promotes the sharing of experience between teachers for the introduction of competencebased learning content

Source: Authors' calculations based on LIZDA survey data

Fig. 5. Teachers' assessment on support for implementation of competence-based education (aggregate of the assessments 'strongly agree' and 'slightly agree', \%), $n=1258$

\section{Societal support}

In the Kurzeme region, it is more common ( $47 \%$ ), but in the Riga region it is uncommon (69\%) that teachers consider it necessary to educate members in municipalities in order to take various decisions on educational development issues (see Table 1).

Table 1

\section{Teachers assessment on societal support for work in the educational sector (aggregate of the assessments 'strongly agree' and 'slightly agree', \%), $n=1258$}

\begin{tabular}{|l|c|c|c|c|c|c|}
\hline No & Statements & Riga & Vidzeme & Kurzeme & Zemgale & Latgale \\
\hline 1. & $\begin{array}{c}\text { In the municipality in which my school is } \\
\text { situated, it is necessary to educate } \\
\text { members of municipality on the } \\
\text { development of the educational sector }\end{array}$ & 69 & 75 & 77 & 75 & 72 \\
\hline 2. & $\begin{array}{c}\text { As one of the options, I welcome the } \\
\text { partial organisation of methodological } \\
\text { work at both national level and at } \\
\text { municipal level. }\end{array}$ & 65 & 62 & 68 & 63 \\
\hline 3. & $\begin{array}{c}\text { Employer provides supervision to teachers } \\
\text { when needed }\end{array}$ & 29 & 26 & 31 & 26 & 29 \\
\hline 4. & $\begin{array}{c}\text { National media needs to reflect more on } \\
\text { good practices in the education sector }\end{array}$ & 88 & 89 & 91 & 88 & 89 \\
\hline
\end{tabular}

\section{Source: Authors' calculations based on LIZDA survey data}

In Kurzeme, teachers have been more critical of organising methodological work at all levels, as well as the need to reflect good practices in the education sector in the media. In this region, employers have provided more frequent supervision for teachers (31\%) than in Vidzeme (26\%) and Zemgale (26\%). When assessing the views of teachers on social support for work in the 
education sector, it can be concluded that there are No statistically significant differences in opinions across regions.

\section{Material and technological support}

Views of teachers on technology provision are summarized in Table 2.

Teachers' assessment on the provision of technical support in the educational establishment (aggregate of the assessments 'strongly agree' and 'slightly agree', \%), $n=1258$

\begin{tabular}{|c|c|c|c|c|c|c|}
\hline No & Statements & Riga & Vidzeme & Kurzeme & Zemgale & Latgale \\
\hline 1. & $\begin{array}{l}\text { The necessary support for technology } \\
\text { use is available }\end{array}$ & 73 & 76 & 77 & 80 & 79 \\
\hline 2. & $\begin{array}{l}\text { There is a computer available with the } \\
\text { Internet connection }\end{array}$ & 83 & 80 & 76 & 83 & 76 \\
\hline 3. & $\begin{array}{c}\text { There is sufficient support with different } \\
\text { programs on computers }\end{array}$ & 72 & 68 & 62 & 72 & 75 \\
\hline 4. & There is unlimited access to the printer & 63 & 70 & 63 & 69 & 78 \\
\hline 5. & There is unlimited access to the copier & 69 & 77 & 75 & 77 & 81 \\
\hline 6. & There is unlimited access to the scanner & 51 & 58 & 58 & 55 & 66 \\
\hline 7. & $\begin{array}{c}\text { There is an opportunity to use an } \\
\text { interactive blackboard in the learning } \\
\text { process }\end{array}$ & 50 & 54 & 54 & 59 & 58 \\
\hline 8. & $\begin{array}{l}\text { A smartphone is available and paid for } \\
\text { using it }\end{array}$ & 20 & 21 & 23 & 24 & 26 \\
\hline 9. & $\begin{array}{l}\text { Municipal Service apartments are } \\
\text { available for attracting teachers }\end{array}$ & 14 & 10 & 7 & 17 & 9 \\
\hline
\end{tabular}

Source: Authors' calculations based on LIZDA survey data

It should be concluded that there are No statistically significant differences in the views of teachers between the regions, but the continued trend is that teachers in Latgale region are more positive in terms of technology provision compared to the teachers of the Riga region. It is positive that in Zemgale municipalities (17\%) and Riga municipalities (14\%) more teachers have access to service apartments what motivates teachers to work in municipalities.

\section{Conclusions}

1) In comparison with other regions, teachers in Latgale and Riga regions are more likely to assess all forms of professional support as important. The regions of Riga and Latgale have statistically significant differences in assessing all types of professional support. There are No such differences between the views of teachers in other regions.

2) The need for financial and societal support is most important for teachers in Riga region, while Latgale teachers consider the need for methodological and material support.

3) Compared to other regions, teachers in Riga and Vidzeme are more critical in their assessments of motivation for work in the teaching profession and its impact on the prestige of the teaching profession. Teachers in Vidzeme more often than in Latvia, on average, agree that the teacher's salary is not motivating so that young people choose a job in this profession.

4) Teachers in Zemgale more often than teachers in the state, on average, agree with the statement that when integrating students with special needs into general education institutions, teachers 
are not paid for additional duties. Teachers in the regions of Riga and Latgale have statistically significant differences in this view.

5) There are statistically significant differences between the regions of Riga and Latgale, as well as the regions of Riga and Zemgale, in teachers' assessments of the lowest salary rate, which should be similar to the average salary in the country, multiplying it by a factor of 1.2.

6) In Latgale, the teachers more frequently strongly agree and slightly agree with the statement that over the last three years, they had to finance their own teacher's professional development from their private means. Regarding this statement, there are statistically significant differences between the regions of Riga and Latgale.

7) There are statistically significant differences between the regions of Riga and Latgale in how teachers are provided with health insurance: more teachers receive it in the Riga region than in Latgale.

8) Professional support measures are being implemented for teachers in Latvia, but there is No common support system in place to address which functions and support measures should be implemented at national level and which at municipal level.

\section{Bibliography}

1. European Union (2018). Teachers and Trainers Matter. How to Support Them in High-performance Apprenticeships and Work-based Learning. 12 Policy Pointers. Luxembourg: Publications Office of the European Union. Retrieved from: http://ec.europa.eu/social/publications Access: 29.01.2019

2. Noteikumi par pedagogiem nepieciesamo izglitibu un profesionalo kvalifikaciju un pedagogu profesionalas kompetences pilnveides kartibu Nr. 569 (Regulations Regarding Procedures for the Development of Education and Vocational Qualifications and Vocational Competencies of Teachers No 569) (2018). Retrieved: https://likumi.Iv/ta/id/301572-noteikumi-par-pedagogiem-nepieciesamo-izglitibu-unprofesionalo-kvalifikaciju-un-pedagogu-profesionalas-kompetences-pilnveides Access: 29.01.2019

3. OECD (2018). Education at a Glance 2018: OECD Indicators. Paris: OECD Publishing. Retrieved: https://read.oecd-ilibrary.org/education/education-at-a-glance-2018_eag-2018-en\#page4 Access: 31.01.2019

4. Roberts, D. L. \& Allen, J. p. (2015). Exploring Ethical Issues Associated with Using Online Surveys in Educational Research. Educational Research and Evaluation, 21(2), pp. 95-108. DOI: $10.1080 / 13803611.2015 .1024421$

5. Sprott, A. R. (2018). Factors that Foster and Deter Advanced Teachers' Professional Development. Teaching and Teacher Education, 77, pp. 321-331. https://doi.org/10.1016/j.tate.2018.11.001

6. Toepoel, V. (2015). Doing Surveys Online. London: Sage Publications, 280 p. 